\title{
PERBEDAAN PENGGUNAAN METODE EKSPERIMEN DENGAN PENDEKATAN INKUIRI DAN VERIFIKASI TERHADAP HASIL BELAJAR SISWA
}

\author{
Febri Rismaningsih \\ Universitas Islam Syekh Yusuf, Jl Maulana Yusuf No 80, Babakan, Kota Tangerang \\ e-mail: febririsma.89@gmail.com
}

\begin{abstract}
Differences in the Use of The Experimental Method of Inquiry and Verification Approach Towards the Students Learning Results. This study was aimed to determine whether there is a difference in the understanding and the concept application as well as the scientific performance between the students who were given a lesson by using the experimental method with guided inquiry and verivication as well as informative approach (lecture). The type of this study is a true experimental study using the randomized pretestposttest control experimental design/ comparison group design with two experimental classes and a control class. The population of this research is all of XI class students in SMAN I Sedayu. The sample taken were 26 students of class XI IPA 1 as an experimental class 1 that was learning with guided inquiry approach, 26 students of class XI IPA 3 as an experimental class 2 that was learning with verification approach and class XI IPA 2 that was learning with informative approach. The hypothesis testing method used was one way ANOVA followed by Post Hoc analysis. The results of this study indicate that there is a positive and significant difference in the lerning results of understanding and concept application among students by teaching the experimental method which used the guided inquiry approach and the verification approach as well as the informative approach lecture). But there is no positive and significant difference in learning results of the scientific performance of the students. The group that learned physics with guided inquiry approach has average understanding and application of the concept better than those that used the verification approach and informative approach (lecture).
\end{abstract}

Keywords : experimental method, inquiry approach, verification approach, learning results.

\begin{abstract}
ABSTRAK: Perbedaan Penggunaan Metode Eksperimen dengan Pendekatan Inkuiri dan Verifikasi Terhadap Hasil Belajar Siswa.Penelitian ini bertujuan untuk mengetahui ada tidaknya perbedaan pemahaman dan penerapan konsep serta kinerja ilmiah antara siswa yang diberi pembelajaran dengan metode eksperimen dengan menggunakan pendekatan inkuiri terbimbing dan verifikasi serta pendekatan informatif (ceramah). Jenis penelitian ini adalah penelitian eksperimen murni yang menggunakan rancangan eksperimen randomized pretest-posttest control/comparison group desain dengan dua kelas eksperimen dan satu kelas kontrol. Populasi dari penelitian ini adalah seluruh siswa kelas XI IPA SMA N 1 Sedayu. sampelnya yaitu 26 siswa dari kelas XI IPA 1 sebagai kelas eksperimen 1 yang diberi pembelajaran dengan pendekatan inkuiri terbimbing, 26 siswa dari kelas XI IPA 3 sebagai kelas eksperimen 2 yang diberi pembelajaran dengan pendekatan verifikasi serta kelas XI IPA 2 yang diberi pembelajaran dengan pendekatan informatif. Metode pengujian hipotesis yang digunakan adalah One Way ANOVA yang dilanjutkan dengan analisis Post Hoc. Hasil penelitian ini menunjukkan bahwa ada perbedaan yang positif dan signifikan pada hasil belajar pemahaman dan penerapan konsep antara siswa yang diberi pembelajaran dengan metode eksperimen yang menggunakan pendekatan inkuiri terbimbing dan pendekatan verifikasi serta pendekatan informatif (ceramah), tetapi tidak ada perbedaan yang positif dan signifikan pada hasil belajar kinerja ilmiah siswa. Pembelajaran fisika dengan pendekatan inkuiri terbimbing memiliki nilai rata-rata pemahaman dan penerapan konsep yang lebih baik dibandingkan kelompok yang menggunakan pendekatan verifikasi dan pendekatan informatif (ceramah).
\end{abstract}

Kata-kata Kunci: Metode eksperimen, Pendekatan Inkuiri, Pendekatan Verifikasi, Hasil Belajar.

Perkembangan teknologi memberi-kan wahana yang memungkinkan sains berkembang dengan pesat. Hal ini menggugah para pendidik untuk dapat merancang dan melaksanakan pendidikan yang lebih terarah pada penguasaan konsep sains, yang dapat bermanfaat dalam kegiatan sehari-hari di masyarakat. Menurut Hamid (2004: 122), pentingnya fisika tidak hanya terletak pada kenyataan, bahwa fisika memberikan kerangka dasar, kerangka konseptual, dan kerangka teoritis pada semua ilmu alamiah tetapi dari 
segi praktis, fisika sangat penting artinya, ini dikarenakan fisika menyiapkan teknik-teknik yang dapat digunakan setiap riset (penelitian) ilmu murni maupun ilmu terapan. Oleh sebab itu, fisika sering disebut sebagai perkusor (pembuka jalan) ilmu dan fisika juga sering disebut sebagai ilmu yang mendasari teknologi.

Pesatnya perkembangan teknologi tidak terlepas dari perkembangan sains. Hal ini menjadi tantangan bagi semua pihak yang terkait langsung ataupun tidak langsung dengan sains. Dalam proses pembelajaran, peran serta guru sangat dituntut sebagai pembimbing dan siswa menemukan sendiri konsep atau fakta yang akan dipelajarinya sehingga muncul kinerja ilmiah siswa. Dewasa ini, kreatif dan antisipatif para guru fisika dalam praktek pembelajaran untuk memaksimalkan peranan siswa masih belum optimal. Hal ini diduga sebagai salah satu faktor penyebab rendahnya kualitas dan kuantitas proses dan produk pembelajaran fisika. Kualitas proses pembelajaran fisika dapat dilihat dari kegiatan pembelajaran yang bersifat konvensional, artinya pemilihan pendekatan, strategi, metode kurang bervariasi. Proses belajar-mengajar cenderung dimulai dengan orientasi dan penyajian informasi yang berkaitan dengan konsep yang akan dipelajari siswa, pemberian contoh soal, dilanjutkan dengan memberikan tes. Kegiatan mengajar yang dilakukan oleh guru sangat mempengaruhi kegiatan belajar siswa. Apabila guru mengajar dengan pendekatan yang bersifat menyajikan atau ekspositori, maka para siswa akan belajar dengan cara menerima, dan apabila guru mengajar dengan menggunakan pendekatan yang lebih mengaktifkan siswa, seperti pendekatan diskoveri/inkuiri, maka para siswa akan belajar dengan cara yang aktif pula. Mengajar bukan lagi usaha untuk menyampaikan ilmu pengetahuan, melainkan juga usaha menciptakan sistem lingkungan yang membelajarkan peserta didik agar tujuan pembelajaran dapat tercapai secara optimal. Mengajar dalam pemahaman seperti ini memerlukan suatu strategi belajar-mengajar yang sesuai. Mutu pengajaran tergantung pada pemilihan strategi yang tepat bagi tujuan yang ingin dicapai, terutama dalam mengembangkan kreativitas dan sikap inovatif subjek didik .
Berdasarkan hasil observasi peneliti di SMA Negeri 1 Sedayu, Proses pembelajaran cenderung masih konvensional. Guru lebih banyak berperan dalam membentuk pengetahuan sehingga siswa cenderung pasif. Guru lebih menekankan pada penjelasan materi secara ceramah dan latihan soal sehingga banyak siswa yang merasa jenuh dan kurang menyukai pelajaran fisika. Dalam pembelajaran, kegiatan praktikum dilakukan terpisah dengan kegiatan pembelajaran. Pada materi pokok fluida statis sendiri tidak menggunakan metode eksperimen karena di laboratorium belum memiliki sejumlah peralatan praktikum yang berhubungan dengan fluida seperti alat pengukur tekanan hidrostatis, hidrometer, manometer dan lain sebagainya. Metode eksperimen hanya digunakan ketika siswa akan menghadapi ujian praktik saja. Namun tidak semua materi bisa dipraktikan, selain karena minimnya keterbatasan alat, praktikum juga harus menyesuaikan pada kondisi peralatan yang akan digunakan, banyak alat-alat yang rusak dan tidak dapat berfungsi dengan baik karena kurangnya perawatan dalam jangka waktu yang lama.

Mengingat kondisi tersebut, tidak mengherankan bahwa guru lebih memilih pendekatan informatif (ceramah) dalam mengajar, karena dengan pendekatan ini bahan yang banyak dapat disampaikan dengan singkat, sehingga materi yang ada pada silabus dapat disampaikan secara menyeluruh dan tepat waktu pada siswa. Jika pembelajaran seperti ini terus diterapkan maka akan berdampak pada kurangnya pemahaman dan penerapan konsep serta keterampilan kinerja ilmiah siswa. Terbukti dengan prestasi IPA (fisika) cenderung lebih rendah dibandingkan dengan mata pelajaran yang lain.

Dalam kegiatan belajar mengajar, siswalah yang terpenting dalam proses belajar, dan bukan guru. Siswa harus aktif bertanya, aktif mengerjakan sesuatu bahan, aktif membuat laporan, aktif mengungkapkan gagasannya. Misalnya dalam pembelajaran fisika, siswa terlibat aktif dalam membuat hipotesis, mengerjakan percobaan, mengumpulkan data, menganalisis dan membuat kesimpulan apakah hipotesisnya cocok atau tidak dengan hasil percobaan yang dilakukan.

Salah satu prinsip dalam pembelajaran yang efektif yaitu menguatkan praktek dalam 
tindakan. Maka dari itu, fisika yang merupakan ilmu yang mempelajari gejala fisis alam melalui kerja ilmiah sangat cocok bila pembelajarannya menggunakan metode eksperimen. Wulandari (2009) pernah melakukan penelitian tentang peranan strategi eksperimen dengan pendekatan induktif (inkuiri) dan deduktif (verifikasi) pada konsep termodinamika ditinjau dari aspek kognitif dan psikomotor untuk siswa kelas XI SMAN 1 Bawang-Banjarnegara. Hasil penelitian ini menunjukkan bahwa pembelajaran fisika dengan model induktif lebih sesuai bagi siswasiswa dalam memahami konsep termodinamika daripada pembelajaran fisika menggunakan strategi eksperimen dengan pendekatan deduktif.

Pendekatan/model pembelajaran dalam metode eksperimen, dapat diklasifikasikan sebagai berikut: deduktif atau verifikasi, induktif, keterampilan teknis, tanya jawab, dan keterampilan proses. Pendekatan inkuiri merupakan pendekatan mengajar yang berusaha meletakkan dasar dan mengembangkan cara berpikir ilmiah. Pendekatan ini menempatkan siswa lebih banyak belajar sendiri, mengembangkan kekreatifan dalam pemecahan masalah. Peranan guru dalam pendekatan inkuiri adalah pembimbing dan fasilitator belajar. Metode eksperimen dengan pendekatan verifikasi merupakan metode eksperimen yang bertujuan untuk membuktikan hukum atau konsep fisika, sebagian besar guru sains pertama kali menyajikan gagasan pokok melalui penyajian, diskusi, dan membaca kemudian diikuti eksperimen untuk menggambarkannya dalam aktivitas-aktivitas nyata .

Baik pendekatan inkuiri maupun verifikasi, keduanya merupakan strategi pembelajaran yaitu cara-cara yang akan dipilih dan digunakan oleh seorang pengajar untuk menyampaikan materi pembelajaran sehingga akan mempermudahkan peserta didik menerima dan memahami materi pembelajaran, yang pada akhirnya tujuan pembelajaran dapat dikuasainya di akhir kegiatan belajar (Uno, 2009: 2-3). Kedua pendekatan tersebut diharapkan dapat meningkatkan kualitas pembelajaran fisika khususnya dalam pemahaman dan penerapan konsep serta kinerja ilmiah.

Berdasarkan uraian diatas, perlu dikembangkan suatu pembelajaran fisika yang mengaktifkan siswa yaitu dengan menggunakan metode eksperimen dengan pendekatan inkuiri terbimbing dan pendekatan verifikasi. Hasil penerapan pendekatan inkuiri terbimbing dan verifikasi dalam pembelajaran dapat digunakan untuk mengetahui pendekatan pembelajaran yang lebih baik diantara keduanya.

\section{METODE}

Penelitian ini berbentuk eksperimen murni (true experimental), dalam metode ini selain kelompok eksperimen juga ada kelompok kontrol yang juga karakteristik dalam variabel-variabelnya sama dengan kelompok eksperimen. Bedanya pada kelompok eksperimen diberi perlakuan khusus (variabel yang akan diuji akibatnya) sedang pada kelompok kontrol diberi perlakuan lain, atau perlakuan yang biasa dilakukan, yang akan dibandingkan hasilnya dengan perlakuan eksperimen.

Desain penelitian yang digunakan adalah Randomized Pretest-Posttest Control/Comparison Group Design. Adapun gambaran desain penelitian yaitu:

Tabel 1.Desain Penelitian

\begin{tabular}{ccccc}
\hline & Kelompok & Prates & Perlakuan & Pascates \\
\hline Acak & $\mathrm{A}\left(K E_{1}\right) \longrightarrow \mathrm{O}_{1}$ & $\mathrm{X}_{1} \longrightarrow \mathrm{O}_{4}$ \\
\hline Acak & $\mathrm{B}\left(K E_{2}\right) \longrightarrow \mathrm{O}_{2}$ & $X_{2} \longrightarrow \mathrm{O}_{5}$ \\
\hline Acak & $\mathrm{C}(K K) \longrightarrow \mathrm{O}_{6}$ \\
\hline
\end{tabular}

Sumber : Sukmadinata (2009: 206)

Keterangan : $K E_{1}$ : kelompok siswa yang diberi pembelajaran fisika dengan pendekatan inkuiri terbimbing, $K E_{2}$ : pendekatan verifikasi, $K K$ : pendekatan informatif (ceramah). $O_{l}$ adalah pelaksanaan pretest pendekatan inkuiri terbimbing, $\mathrm{O}_{2}$ : pendekatan verifikasi, $\mathrm{O}_{3}$ : pendekatan informatif. $X_{I}$ : penilaian terhadap kinerja ilmiah siswa pendekatan inkuiri 
terbimbing, $\mathrm{X}_{2}$ : pendekatan verifikasi. $\mathrm{O}_{4}$ : pelaksanaan posttest pendekatan inkuiri terbimbing, $\mathrm{O}_{5}$ : pendekatan verifikasi, $\mathrm{O}_{6}$ : pendekatan informatif

Populasi dalam penelitian ini berjumlah 101 siswa, sedangkan kepercayaan sampel populasi yang digunakan adalah $95 \%$ atau tingkat kesalahan 5\%. Berdasarkan tabel yang dikembangkan oleh Isaac dan Michael, jika jumlah populasi 100 maka jumlah sampel adalah 78. Populasi dari penelitian ini adalah seluruh siswa kelas XI IPA SMA N 1 Sedayu yang terdiri dari 3 kelas. Masing-masing kelas berjumlah 35 siswa untuk XI IPA 1, 31 siswa untuk XI IPA 2 dan 35 siswa untuk kelas XI IPA 3. Teknik pengambilan sampel dilakukan secara simple random sampling, Berdasarkan teknik tersebut didapatkan kelas XI IPA 1 sebagai kelas eksperimen 1, XI IPA 3 sebagai kelas eksperimen 2 dan kelas XI IPA 2 sebagai kelas kontrol.

Pembelajaran fisika dengan pendekatan inkuiri terbimbing dan pendekatan verifikasi dalam bentuk rencana pelaksanaan pembelajaran (RPP) inkuiri terbimbing, dan lembar kegiatan siswa (LKS) inkuiri terbimbing. Adapun langkah-langkah dalam LKS inkuiri adalah sebagai berikut: 1) pemberian pertanyaan-pertanyaan untuk didiskusikan guna menyusun rumusan hipotesis, 2) merumuskan hipotesis, 3) merancang langkah kerja eksperimen, 4) melakukan eksperimen, 5) menulis data hasil eksperimen, dan 6) pengambilan kesimpulan.

LKS yang digunakan untuk kelompok inkuiri susunannya sesuai dengan tujuan eksperimen yaitu penemuan konsep fisika. Adapun langkah-langkah dalam LKS verifikasi adalah sebagai berikut : 1) dasar teori, 2) tujuan eksperimen, 3) urutan kerja eksperimen, 4) menulis data hasil eksperimen, dan 5) penarikan kesimpulan. LKS verifikasi ini disesuaikan dengan tujuan eksperimen yaitu membuktikan teori/konsep.

Instrumen yang digunakan dalam pengumpulan data adalah:

a. Tes Pemahaman Konsep Fisika Siswa, Tes hasil belajar ranah kognitif siswa ini digunakan dua kali dalam penelitian yaitu saat pretest guna mengetahui kemampuan awal kognitif siswa dan pada saat posttest untuk menjaring data hasil belajar ranah kognitif siswa. Pada penelitian ini hanya dibatasi pada ranah kognitif $C_{1}$ sampai $C_{4}$ karena menurut Budiono dan Sidi (2003: 11) pembelajaran fisika di Sekolah Menengah Atas lebih menekankan pada pemahaman, aplikasi, konsep dan analisis.

b. Lembar Observasi Kinerja Ilmiah Siswa

Lembar observasi kinerja ilmiah berjumlah delapan set sesuai dengan jumlah lembar kegiatan siswa. Rerata tiap set memiliki 10 butir penilaian. Instrumen ini berbentuk skala dengan skor $0-3$. Data yang diperoleh adalah berbentuk data ordinal. Analisa data yang digunakan adalah uji hipotesis komparatif lebih dari dua sampel yaitu analisis varians satu jalan (One way ANOVA) yang mana dalam uji ini data yang digunakan adalah data interval /rasio, sehingga data ordinal harus diubah kedalam data rasio. Adapun cara mengubahnya yaitu dengan mengubah nilai yang telah diperoleh kedalam $z$ score selanjutnya dikonversikan kedalam $T$ score.

Menurut Arikunto (2009: 268) standard score atau $z$ score adalah angka yang menunjukkan perbandingan perbedaan score seseorang dari mean, dengan standar deviasinya. Standard score ini lebih mempunyai arti dibandingkan dengan suatu standar yang sama. Langkah untuk menentukan $z$ score yaitu harus diketahui ratarata skor dari kelompok dan standar deviasi dari skor-skor tersebut. Adapun rumus yang digunakan yaitu :

$$
z=\frac{X-M}{S D}
$$

$z=$ nilai baku

Menurut Arikunto (2009: 271-272) $T$ score adalah angka skala yang menggunakan Mean=50 dan $\mathrm{SD}=10$. Skala $T$-score dapat dicari dengan cara mengalikan $z$ score dengan 10, kemudian ditambah 50. Adapun rumus yang digunakan yaitu :

$$
\begin{array}{r}
T=10 z+50 \\
\text { atau } T=50+\frac{10(X-M)}{S D} \ldots
\end{array}
$$

\section{c. Uji Coba Instrumen}

Cara untuk mengetahui validitas dan reliabilitas konstruk tiap-tiap butir instrumen yaitu dilakukan dengan uji coba instrumen. Dalam penelitian ini, uji coba instrumen dilakukan di luar sampel penelitian. Mengingat sampel yang digunakan adalah semua siswa kelas XI IPA yang terdiri dari 3 kelas, maka uji coba instrumen dilakukan diluar sekolah yaitu SMA N 1 Depok dengan asumsi bahwa 
siswa kelas XI IPA pada sekolah tersebut sudah pernah mendapat materi fluida statis.

Pada penelitian ini, uji validitas instrumen tes pemahaman dan penerapan konsep dilakukan sebanyak 50 butir soal. Uji validitas dilakukan dengan bantuan program ITEMAN. Dari hasil uji validitas diperoleh 30 soal yang lolos.

Pada penelitian ini dalam menentukan reabilitas menggunakan bantuan program komputer ITEMAN versi 3.00. Pada tes pemahaman dan penerapan konsep, perhitungan koefisien reabilitas dapat dilihat dari hasil analisis ITEMAN versi 3.00 pada bagian alpha di bagian scale statistic. Sebelum soal yang tidak valid dihilangkan, diperoleh koefisien alpha sebesar 0,733. Namun, setelah soal yang tidak valid dihilangkan hasil koefisien nilai alpha pada instrumen tes kognitif siswa menunjukkan nilai 0,853 berarti soal ini termasuk kategori sangat reliabel.

kriteria koefisien reliabilitas yang digunakan dapat dinyatakan sebagai berikut :

Tabel 2. Kategori Reliabilitas Soal

\begin{tabular}{cc}
\hline $\begin{array}{c}\text { Koefisien } \\
\text { Reliabilitas }\end{array}$ & $\begin{array}{c}\text { Kategori } \\
\text { Reliabilitas }\end{array}$ \\
\hline $0,0-0,2$ & Kurang reliabel \\
$0,2-0,4$ & Agak reliabel \\
$0,4-0,6$ & Cukup reliabel \\
$0,6-0,8$ & Reliabel \\
$0,8-1,0$ & Sangat reliabel \\
\hline
\end{tabular}

Sumber : Triton (2006: 248)

Teknik pengumpulan data yang digunakan dalam metode tes yaitu dibagi menjadi tiga tahap, pertama adalah mengumpulkan data kemampuan awal pemahaman dan penerapan konsep fisika siswa yang dilakukan dengan memberikan tes awal (pretest). Tahap kedua dilakukan dengan memberikan perlakuan kepada dua kelompok eksperimen. Tahap ketiga adalah dengan memberikan tes akhir (posttest) untuk mengetahui hasil belajar siswa. Langkah pengumpulan data untuk kinerja ilmiah yaitu berupa lembar observasi yang diisi oleh observer atau guru dalam tiap-tiap komponen. kelas kontrol (pendekatan informatif) juga diberi satu kali tes kinerja ilmiah untuk membandingkannya dengan kelas eksperimen. Ketiga kelas mendapatkan materi yang sama yaitu mengenai fluida statis.
Sebelum analisis dilakukan, terlebih dahulu harus dilakukan uji persyaratan analisis. Langkah ini penting karena hasilnya menentukan teknik analisis yang seharusnya dilakukan. Pengujian tersebut meliputi :

a. Normalitas Sebaran Data

Uji normalitas digunakan untuk mengetahui apakah data berdistribusi normal atau tidak. Uji normalitas dilakukan dengan uji Kolmogorov Smirnov pada skor data pretest dan posttest.. Menurut Triton (2006: 79) persyaratan data disebut normal jika probabilitas atau $p>0,05$ pada uji normalitas Kolmogorov Smirnov.

b. Homogenitas Varians

Uji Homogenitas varians dimaksudkan untuk mengetahui apakah sampel yang diambil secara acak berasal dari populasi yang homogen atau tidak. Uji yang dilakukan adalah uji homogenitas varians dengan menggunakan One way ANOVA. Prasyarat uji anova yaitu homogenitas (mempunyai varians sama). Hipotesis asumsi adalah :

$H_{0}$ : Ketiga varians populasi adalah homogen

$H_{a}$ : Ketiga varians populasi adalah tidak homogen

Jika harga probabilitas perhitungan lebih besar dari 0,05 pada taraf signifikansi 5\%. Maka $H_{0}$ diterima atau ketiga varians populasi homogen sehingga asumsi homogenitas telah terpenuhi untuk melanjutkan One way ANOVA.

Berdasarkan uji persyaratan analisis yang telah dilakukan maka dapat ditentukan bahwa hipotesis akan diuji menggunakan One way ANOVA. Uji ini digunakan karena data penelitian terdistibusi normal dan bersifat homogen.

Langkah selanjutnya yang digunakan adalah yaitu dengan menggunakan analisis Post Hoc. Pada prinsipnya analisis Post Hoc bertujuan mengetahui lebih rinci mengenai pasangan kelompok sampel yang saling berbeda secara signifikan dan pasangan kelompok sampel yang tidak berbeda. Pada analisis Post Hoc terdapat Multiple Comparison yang didalamnya terdapat 2 baris untuk uji hasil Bonferroni dan Tukey HSD. Pada kedua uji ini dilakukan uji signifikansi perbedaan antara ketiga kelompok. Dasar pengambilan keputusannya yaitu jika probabilitas >0,05 maka $\mathrm{H}_{0}$ diterima sedangkan jika probabilitas $<0,05$ maka $\mathrm{H}_{0}$ ditolak. 
Secara praktis, hasil uji signifikansi dapat diketahui dengan cepat pada output yang ada, yaitu dengan adanya tanda * pada kolom mean difference (I-J). Adanya tanda * menunjukkan bahwa perbedaan rata-rata adalah signifikan, dan sebaliknya, tidak adanya tanda * menunjukkan bahwa perbedaan rata-rata tidak signifikan.

Interpretasi hasil uji lanjut One way ANOVA dapat dilihat pada Homogeneous Subsets. Dalam Homogeneous Subsets akan dicari kelompok sampel yang perbedaan rataratanya tidak signifikan. Menurut Triton (2006: 203) berdasarkan hasil analisis dan interpretasi atas uji Post Hoc maupun Homogeneous Subsets, dapat disimpulkan bahwa hasil pengujian Bonferroni dan Tukey adalah saling melengkapi terhadap hasil uji Homogeneous Subsets.

Kriteria penerimaan atau penolakan $H_{0}$ pada taraf signifikansi 5\% dengan menggunakan program SPSS 16.0 adalah melalui signifikansi atau probabilitas yaitu apabila probabilitas $>0,05$ maka $H_{0}$ diterima sedangkan jika probabilitas $<0,05$ maka $H_{0}$ ditolak.

\section{HASIL DAN PEMBAHASAN}

\section{Hasil}

\section{Data Kemampuan Awal Pemahaman dan Penerapan Konsep Siswa \\ Kemampuan awal ini diperoleh melalui} tes hasil belajar pemahaman dan penerapan konsep siswa secara ringkas dapat dilihat pada Tabel 3.

2. Data Hasil Belajar Pemahaman dan Penerapan Konsep Siswa

Data hasil belajar pemahaman dan penerapan konsep fisika siswa pada dua kelas eksperimen dan satu kelas kontrol. Secara ringkas, data dapat disajikan pada Tabel 4.

Tabel 3. Parameter Data Kemampuan Awal Pemahaman dan Penerapan Konsep Siswa

\begin{tabular}{lcccc}
\hline \multicolumn{1}{c}{ Kelas } & \multirow{2}{*}{ Rerata } & Simpangan & \multicolumn{2}{c}{ Nilai } \\
\cline { 4 - 5 } & & Baku & Terendah & Tertinggi \\
\hline $\begin{array}{l}\text { Kelas } \\
\text { Eksperimen 1 }\end{array}$ & 3,65 & 1,17 & 1,66 & 5,66 \\
$\begin{array}{l}\text { Kelas } \\
\text { Eksperimen 2 }\end{array}$ & 3,65 & 1,47 & 1,00 & 6,00 \\
Kelas Kontrol & 3,67 & 1,17 & 1,00 & 5,66 \\
\hline
\end{tabular}

Tabel 4. Parameter Data Hasil Belajar Pemahaman dan Penerapan Konsep Siswa

\begin{tabular}{ccccc}
\hline \multirow{2}{*}{ Kelas } & \multirow{2}{*}{ Rerata } & Simpangan & \multicolumn{2}{c}{ Nilai } \\
\cline { 4 - 5 } Kelas & 7,52 & 0,34 & 7,00 & 8,33 \\
Eksperimen 1 & & & & \\
$\quad$ Kelas & 6,97 & 0,46 & 6,00 & 7,66 \\
Eksperimen 2 & 6,76 & 0,61 & 4,33 & 7,66 \\
Kelas Kontrol & &
\end{tabular}

\section{Data Hasil Belajar Kinerja Ilmiah Siswa}

Tabel 5. Parameter Data Kemampuan Kinerja ilmiah siswa

\begin{tabular}{lcccc}
\hline \multirow{2}{*}{ Kelas } & \multirow{2}{*}{ Rerata } & \multirow{2}{*}{ Simpangan Baku } & \multicolumn{2}{c}{ Nilai dalam $\boldsymbol{T}$ score } \\
\cline { 4 - 5 } & & & Terendah & Tertinggi \\
\hline Kelas Eksperimen 1 & 53,15 & 13,81 & 29,00 & 85,00 \\
Kelas Eksperimen 2 & 52,73 & 13,32 & 28,00 & 78,00 \\
Kelas Kontrol & 51,34 & 15,46 & 17,00 & 73,00 \\
\hline
\end{tabular}




\section{Pengujian Prasyaratan Analisis}

\section{A. Uji Normalitas}

Tabel 6. Data Uji Normalitas dengan

Kolmogorov Smirnov untuk satu sampel

\begin{tabular}{lcc}
\hline Data & $\begin{array}{c}\text { Taraf } \\
\text { signifikansi }(\boldsymbol{p})\end{array}$ & Kesimpulan \\
\hline Pretest & 0,424 & Data terdistribusi normal \\
Posttest & 0,091 & Data terdistribusi normal \\
\hline
\end{tabular}

\section{B. Uji Homogenitas}

Tabel 7. Data Uji Homogenitas Varians dengan Levene Test

\begin{tabular}{ccc}
\hline Data & $\boldsymbol{P}$ & Kesimpulan \\
\hline Pretest & 0,231 & Varians homogen \\
Posttest & 0,491 & Varians homogen \\
\hline
\end{tabular}

5. Pengujian Hipotesis

A. Perbedaan hasil belajar pemahaman dan penerapan konsep siswa dengan pendekatan inkuiri terbimbing, pendekatan verifikasi serta pendekatan informatif (ceramah).

Tabel 8. Data Uji Perbedaan Hasil Belajar Pemahaman dan Penerapan Konsep Siswa

\begin{tabular}{lccccc}
\hline & $\begin{array}{c}\text { Sum of } \\
\text { Squares }\end{array}$ & Df & $\begin{array}{c}\text { Mean } \\
\text { Square }\end{array}$ & $F$ & Sig. \\
\hline Between Groups & 7.956 & 2 & 3.978 & 16.839 & .000 \\
Within Groups & 17.718 & 75 & .236 & & \\
\hline Total & 25.675 & 77 & & & \\
\hline
\end{tabular}

Tabel 9. Uji Lanjut Perbedaan Hasil Belajar Pemahaman dan Penerapan Konsep Siswa ( Multiple Comparisons)

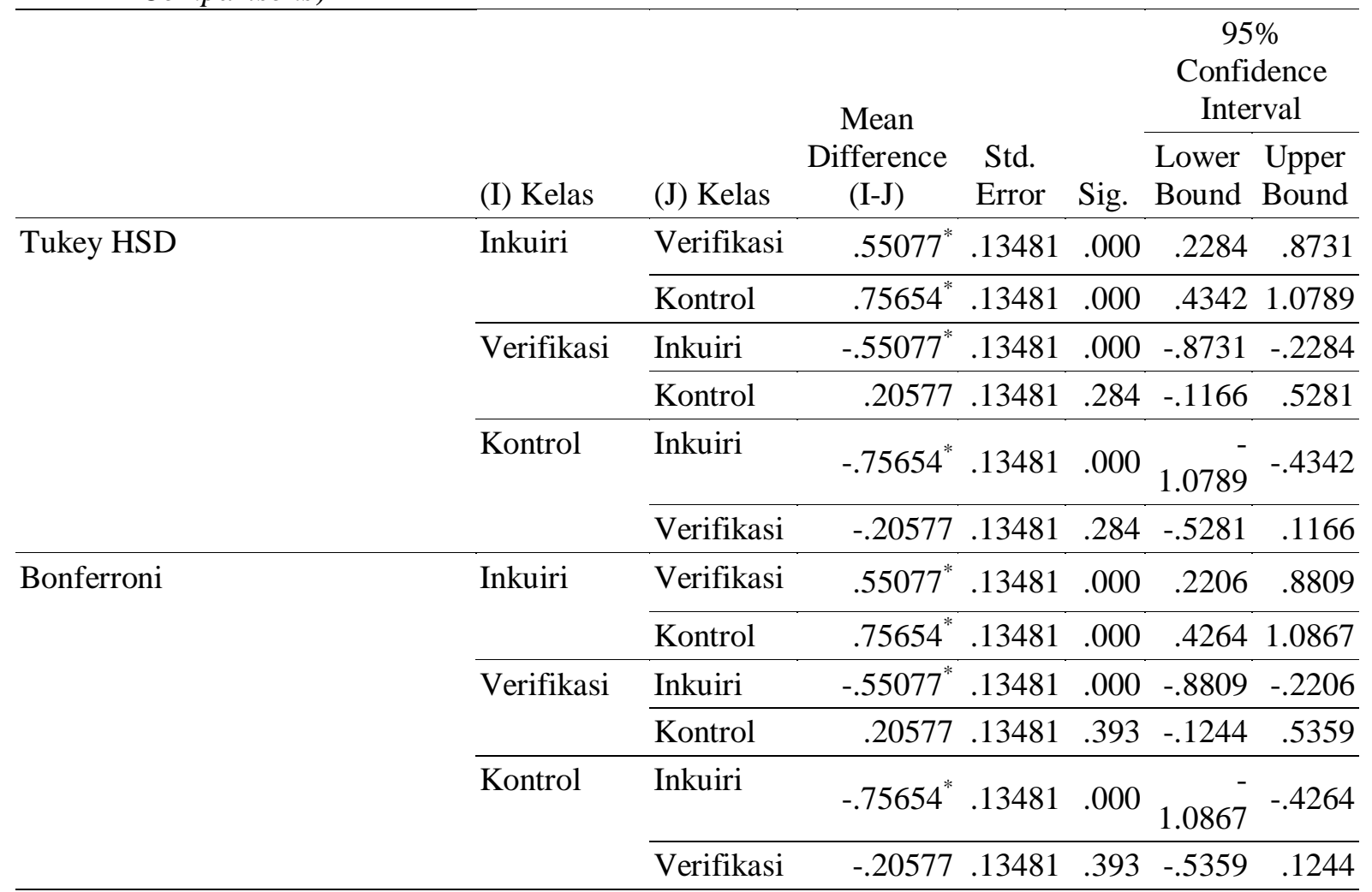


Tabel 10. Homogeneous Subsets

\begin{tabular}{lllcc}
\hline & & \multicolumn{3}{c}{$\begin{array}{c}\text { Subset for alpha } \\
=0.05\end{array}$} \\
\cline { 4 - 5 } & Kelas & $\mathrm{N}$ & 1 & 2 \\
\hline Tukey & Kontrol & 26 & 6.7650 & \\
HSD & Verifikasi & 26 & 6.9708 & \\
& Inkuiri & 26 & & 7.5215 \\
& Sig. & & .284 & 1.000 \\
\hline
\end{tabular}

B. Perbedaan hasil belajar kinerja ilmiah siswa dengan pendekatan inkuiri terbimbing, pendekatan verifikasi serta pendekatan informatif (ceramah).
Tabel 11. Data Uji Perbedaan Hasil Belajar Kinerja Ilmiah Siswa

\begin{tabular}{lrrrrrr} 
& $\begin{array}{c}\text { Sum of } \\
\text { Squares }\end{array}$ & & Mean & & \\
& Df & Square & $F$ & Sig. \\
\hline $\begin{array}{l}\text { Between } \\
\text { Groups }\end{array}$ & 45.308 & 2 & 22.654 & .112 & .894 \\
Within & & & & & \\
Groups & 15163.154 & 75 & 202.175 & & \\
\hline Total & 15208.462 & 77 & & &
\end{tabular}

Tabel 12. Uji Lanjut Perbedaan Hasil Belajar Kinerja Ilmiah Siswa ( Multiple Comparisons)

\begin{tabular}{|c|c|c|c|c|c|c|c|}
\hline & \multirow[b]{2}{*}{ (I) Kelas } & \multirow[b]{2}{*}{ (J) Kelas } & \multirow{2}{*}{$\begin{array}{c}\text { Mean } \\
\text { Difference } \\
(\mathrm{I}-\mathrm{J})\end{array}$} & \multirow{2}{*}{$\begin{array}{l}\text { Std. } \\
\text { Error }\end{array}$} & \multirow[b]{2}{*}{ Sig. } & \multicolumn{2}{|c|}{ 95\% Confidence Interval } \\
\hline & & & & & & Lower Bound & Upper Bound \\
\hline \multirow[t]{6}{*}{ Tukey HSD } & Inkuiri & Verifikasi & .500 & 3.944 & .991 & -8.93 & 9.93 \\
\hline & & Kontrol & 1.808 & 3.944 & .891 & -7.62 & 11.24 \\
\hline & Verifikasi & Inkuiri & -.500 & 3.944 & .991 & -9.93 & 8.93 \\
\hline & & Kontrol & 1.308 & 3.944 & .941 & -8.12 & 10.74 \\
\hline & Kontrol & Inkuiri & -1.808 & 3.944 & .891 & -11.24 & 7.62 \\
\hline & & Verifikasi & -1.308 & 3.944 & .941 & -10.74 & 8.12 \\
\hline \multirow[t]{6}{*}{ Bonferroni } & Inkuiri & Verifikasi & .500 & 3.944 & 1.000 & -9.16 & 10.16 \\
\hline & & Kontrol & 1.808 & 3.944 & 1.000 & -7.85 & 11.47 \\
\hline & Verifikasi & Inkuiri & -.500 & 3.944 & 1.000 & -10.16 & 9.16 \\
\hline & & Kontrol & 1.308 & 3.944 & 1.000 & -8.35 & 10.97 \\
\hline & Kontrol & Inkuiri & -1.808 & 3.944 & 1.000 & -11.47 & 7.85 \\
\hline & & Verifikasi & -1.308 & 3.944 & 1.000 & -10.97 & 8.35 \\
\hline
\end{tabular}

Tabel 13. Homogeneous Subsets

\begin{tabular}{lllc}
\hline & & & $\begin{array}{c}\text { Subset for } \\
\text { alpha }=0.05\end{array}$ \\
\cline { 3 - 4 } & Kelas & $\mathrm{N}$ & 1 \\
\hline Tukey & Kontrol & 26 & 51.35 \\
HSD & Verifikasi & 26 & 52.65 \\
& Inkuiri & 26 & 53.15 \\
& Sig. & & .891 \\
\hline
\end{tabular}

\section{Pembahasan}

1. Perbedaan hasil belajar pemahaman dan penerapan konsep antara siswa dengan pendekatan inkuiri terbimbing, pendekatan verifikasi serta pendekatan informatif (ceramah).

Berdasarkan hasil analisis, dapat dilihat bahwa ada perbedaan hasil belajar pemahaman dan penerapan konsep antara siswa dengan pendekatan inkuiri terbimbing, pendekatan verifikasi dan pendekatan informatif (ceramah). Adanya perbedaan ini didasarkan pada kenyataan bahwa dengan alokasi waktu 
yang sama, siswa yang menggunakan pendekatan inkuiri terbimbing akan lebih cepat untuk mengkonstruk suatu konsep fisika daripada siswa yang diberi pembelajaran dengan pendekatan verifikasi dan informatif (ceramah). Hal ini dikarenakan pada pendekatan inkuiri terbimbing siswa diberikan kesempatan untuk mengembangkan konsepkonsep, prinsip-prinsip, dan hukum-hukum melalui pengalaman langsung sebelum ide-ide tersebut didiskusikan di depan kelas.

Melalui pengalaman langsung yang diperoleh tersebut siswa tidak akan mudah melupakan serangkaian kegiatan dari observasi-observasi yang telah dilakukan. Hal ini sesuai dengan teori H.E Amstrong (1992) yang dikutip oleh Zuhdan K. Prasetyo (2001: 1.7) yang menyatakan bahwa anak-anak harus dilatih untuk "menemukan" yang melibatkan kemampuan melahirkan observasi, mengemukakan alasan, dan kemampuan mengingat. Melalui serangkaian aktivitas pada pendekatan ini dapat membantu siswa memahami konsep dan prinsip lebih baik.

Faktor kedua yang menyebabkan perbedaan diatas adalah pada pendekatan verifikasi, siswa telah mendapat konsep, teori maupun prinsip dari guru sehingga tidak mengalami sendiri menemukan konsep, teori, dan prinsip melainkan hanya membuktikannya. Siswa memiliki pemahaman dan penerapan konsep dari teori yang telah mereka peroleh tanpa melalui pengalaman langsung. Dengan demikian, konsep yang mereka dapatkan merupakan konsep yang sudah jadi, hal ini memungkinkan siswa mudah melupakan konsep tersebut dan kurang memahami apa yang ia peroleh.

Siswa yang diberi pembelajaran dengan menggunakan metode ceramah cenderung pasif. Biasanya siswa hanya mendengarkan apa yang disampaikan guru didepan kelas (teacher centered). Siswa hanya memiliki pemahaman konsep dari apa yang disampaikan oleh guru ataupun sekedar informasi dari sumber buku yang mereka baca tanpa mengalami serangkaian kegiatan observasi untuk menemukan konsep atau membuktikannya. Hal ini memungkinkan kurangnya pemahaman dan penerapan konsep siswa.

Pada serangkaian kegiatan dalam proses inkuiri cenderung melibatkan rasa ingin tahu dan rangsangan keterlibatan aktif dalam belajar, dimana sifat pasif perlu dihindari, karena inkuiri menghendaki keterlibatan siswa secara konsisten pada tingkat tinggi. Dengan demikian diharapkan siswa dapat menajamkan kemampuan mereka dalam mendesain dan menggunakan proses inkuiri sehingga pemahaman dan penerapan konsep yang mereka dapatkan lebih baik. Hal ini sesuai dengan teori Gagne (1970) dalam Zuhdan K. Prasetyo (2001: 1.10) yang menyatakan pendekatan inkuiri terpusat pada pemecahan masalah (problem solving), pemecahan masalah terdiri dari penggunaan prinsipprinsip atau aturan-aturan untuk mencapai tujuan yang berarti. Apa yang dipelajari dalam pemecahan masalah merupakan prinsip atau aturan yang tingkatannya lebih tinggi. Pemecahan masalah merupakan suatu bentuk aktivitas mental secara aktif yang memungkinkan terbentuknya pemikiran ilmiah.

Dalam proses inkuiri mencoba membawa peserta didik ke dalam situasi yang memberikan kesempatan pada dirinya untuk menggunakan apa yang telah diketahui dan menyadari apa yang mereka lakukan itu adalah perolehan mereka sendiri, bukan perolehan karena guru. Hal ini sesuai dengan teori Dewey (1933) dalam Buchari Alma dkk (2008: 55) menyatakan pendekatan inkuiri menekankan pada pentingnya "usaha sadar" dalam mengembangkan berfikir kritis dengan cara terus menerus menguji nilai-nilai dan pengetahuan yang ada.

Melalui pendekatan inkuiri dapat membantu siswa mengembangkan metode atau cara-cara memproses informasi yang diperoleh dari lingkungannya. Hal ini sesuai dengan teori yang dikemukakan oleh Niles (1965) dalam Dadang Sulaeman (1988: 151) pendekatan induktif (inkuiri) merupakan strategi pemrosesan informasi dengan menitikberatkan kepada pengembangan keterampilan-keterampilan proses dan pengetahuan tentang isi, dan merupakan alat untuk mengembangkan keterampilanketerampilan intelektual siswa.

Berdasarkan hasil pengujian, asumsi dan beberapa teori yang mendukung pendekatan inkuiri, maka pembelajaran ini sesuai dan dapat diterapkan pada siswa-siswa kelas XI IPA SMA N 1 Sedayu. 


\section{Perbedaan hasil belajar kinerja ilmiah antara siswa dengan pendekatan inkuiri terbimbing, pendekatan verifikasi serta pendekatan informatif (ceramah).}

Pada hipotesis diperkirakan bahwa hasil belajar kinerja ilmiah siswa dengan pendekatan verifikasi lebih tinggi daripada siswa dengan pendekatan inkuiri terbimbing dan pendekatan informatif (ceramah). Hal itu disebabkan pendekatan inkuiri terbimbing frekuensi percobaan dituntut lebih tinggi karena proses memperoleh data percobaan mempunyai fungsi untuk mencari atau menemukan suatu konsep fisika. Berbeda dengan fungsi data percobaan pada pendekatan verifikasi dan pendekatan informatif (ceramah). Pendekatan verifikasi digunakan untuk memperjelas dan membuktikan kebenaran suatu konsep fisika. Pendekatan informatif (ceramah) akan menjadi setara dengan pendekatan verifikasi jika setelah konsep dan teori diberikan oleh guru langsung dilanjutkan oleh kegiatan praktikum.

Namun dalam penelitian ini, pendekatan verifikasi dan informatif perbedaannya terletak pada frekuensi percobaan. Pada pendekatan verifikasi percobaan dilakukan 4 kali untuk setiap sub materi pokok, sedangkan pendekatan informatif hanya dilakukan sekali yaitu pada LKS 4 yang digunakan untuk tes kinerja ilmiah ketiga kelompok. Dengan demikian diharapkan salah satu dari kelas eksperimen memiliki perbedaan dengan kelas kontrol, semakin sering kelas eksperimen melakukan percobaan maka semakin baik pula kinerja ilmiahnya.

Frekuensi pengambilan data yang tinggi pada kerja laboratorium inkuiri terbimbing dapat mengakibatkan tersitanya waktu dan kebosanan pada siswa. Kekurangan waktu dapat menyebabkan siswa melakukan percobaan tergesa-gesa, sehingga hasil belajar kinerja ilmiah tidak optimal. Pada pendekatan verifikasi, siswa hanya memperjelas dan membuktikan kebenaran suatu konsep fisika sehingga waktu yang dibutuhkan akan lebih singkat dan tidak menimbulkan kebosanan.

Demikian juga dalam penyusunan laporan, seharusnya siswa dengan pendekatan verifikasi akan lebih baik dalam menganalisis hasil percobaan. Hal tersebut mungkin karena mereka sudah mengerti apa yang seharusnya dari percobaan yang telah dilakukan. Selain itu mereka tidak mengalami kebingungan karena apa yang mereka dapatkan adalah sesuatu yang benar secara teoritis. Hal seperti ini tidak terjadi pada kerja laboratorium inkuiri terbimbing yang ditandai dengan masih ditemukannya siswa yang mengalami kesulitan dalam menganalisis data percobaan.

Berdasarkan penelitian, beberapa asumsi diatas tidak sepenuhnya terjadi. Tidak terdapatnya perbedaan antara ketiga kelompok ini karena ketidaksesuaian yang direncanakan oleh peneliti dengan yang terjadi di lapangan. Pada pelaksanaan tes kinerja ilmiah, kelas inkuiri telah melaksanakan tes kinerja ilmiah terlebih dahulu, hal ini berjalan sesuai dengan Rencana Pelaksanaan Pembelajaran (RPP). Berbeda dengan kelas verifikasi dan kelas kontrol yang pelaksanaan tes kinerja ilmiahnya terpaut selang waktu yang cukup lama dengan kelas inkuiri, dikarenakan adanya pelaksanaan Ujian Nasional (UNAS) kelas XII SMA N 1 Sedayu. Hal ini berpengaruh pada kemampuan siswa untuk mengingat materi yang sudah diberikan sebelumnya, selain itu siswa lebih banyak terfokus pada mata pelajaran yang lain karena pelaksanaan tes kinerja ilmiah bersamaan dengan pelaksanaan ulangan harian beberapa mata pelajaran. Hal ini menyebabkan banyak siswa yang tidak mempelajari kembali materi yang telah diberikan sehingga pada pelaksanaan tes kinerja ilmiah hasilnya kurang maksimal.

\section{SIMPULAN}

Berdasarkan hasil penelitian dan analisa data dapat disimpulkan sebagai berikut : 1) Terdapat perbedaan yang yang positif dan signifikan pada hasil belajar pemahaman dan penerapan konsep antara siswa dengan pendekatan inkuiri terbimbing, pendekatan verifikasi dan pendekatan informatif (ceramah). Berdasarkan analisis penelitian, kelompok dengan pendekatan inkuiri terbimbing memiliki nilai rata-rata pemahaman dan penerapan konsep yang lebih baik dibandingkan kelompok yang menggunakan pendekatan verifikasi dan pendekatan informatif (ceramah). Pendekatan verifikasi memiliki nilai rata-rata pemahaman dan penerapan konsep yang lebih baik dibandingkan kelompok yang menggunakan pendekatan informatif (ceramah). 2) Tidak ada perbedaan yang positif dan signifikan pada hasil belajar kinerja ilmiah antara siswa dengan pendekatan inkuiri terbimbing, 
pendekatan verifikasi dan pendekatan informatif (ceramah).

\section{DAFTAR RUJUKAN}

Alma, B. 2008. Guru Profesional. Bandung: Alfabeta.

Arikunto, S. 2009. Dasar-dasar Evaluasi Pendidikan. Jakarta: Bumi Aksara.

Budiono dan Sidi, I. J. 2003. Standar Kompetensi Mata Pelajaran Fisika SMA dan MA. Puskur Balitbang. Jakarta. [online]. http:// sasterpadu.tripod.comsas.storeFisika1 5_55/docpdf. Diakses : 28 Juni 2010.

Hamid, A. A. 2004. Kajian Fisika Sekolah. Diktat tidak diterbitkan. Yogyakarta: FMIPA Universitas Negeri Yogyakarta.

Prasetyo, Z. K., dkk. 2001. Kapita Selekta Pembelajaran Fisika. Jakarta: Universitas Terbuka.

Sukmadinata, N. S. 2009. Metode Penelitian Pendidikan. Bandung: Remaja Rosdakarya.

Sulaeman, D. 1998. Teknologi/Metodologi Pengajaran. Jakarta: Departemen Pendidikan dan Kebudayaan.

Triton P.B. 2006. SPSS 13.0 Terapan Riset Statistik Parametrik. Yogyakarta: Andi.

Uno, H. B., dkk. 2009. Model Pembelajaran Menciptakan Proses Belajar Mengajar yang Kreatif dan Efektif. Jakarta: Bumi Aksara.

Wulandari, A. T. 2009. Peranan Strategi Eksperimen dengan Model Induktif dan Deduktif Pada Konsep Termodinamika Ditinjau dari Aspek Kognitif dan Psikomotor Untuk Siswa Kelas XI SMA Negeri I BawangBanjarnegara. Skripsi tidak diterbitkan. Yogyakarta: FMIPA Universitas Negeri Yogyakarta, 